\title{
Homeobox Protein Engrailed-1
}

National Cancer Institute

\section{Source}

National Cancer Institute. Homeobox Protein Engrailed-1. NCI Thesaurus. Code

C114955.

Homeobox protein engrailed-1 (392 aa, $40 \mathrm{kDa}$ ) is encoded by the human EN1 gene.

This protein plays a role in both transcriptional regulation and embryonic development. 